\title{
Effects of Sudden Stratospheric Warming Events on the Distribution of Total Column Ozone over Polar and Middle Latitude Regions
}

\author{
Vazhathottathil Madhu \\ Department of Atmospheric Sciences, School of Marine Sciences, Cochin University of Science and Technology, \\ Cochin, India \\ Email: madhuv68@gmail.com
}

Received 15 January 2016; accepted 4 February 2016; published 21 April 2016

Copyright (C) 2016 by author and Scientific Research Publishing Inc. This work is licensed under the Creative Commons Attribution International License (CC BY). http://creativecommons.org/licenses/by/4.0/

(c) (i) Open Access

\section{Abstract}

In winter the polar stratosphere is extremely cold. During the Sudden Stratospheric Warming events, the polar stratospheric temperature rises concurrently zonal-mean zonal flow weakens over a short period of time. As the zonal flow weakens, the stratospheric circulation becomes highly asymmetrical and the stratospheric polar vortex is displaced off the pole. The polar stratospheric temperature rises by $50^{\circ} \mathrm{C}$ and the stratospheric circumpolar flow reverses direction in a span of just few days. Sudden Stratospheric Warming (SSW) leads to significant changes in the rate of several chemical reactions which occur in the polar stratosphere. During such events, the dynamical fields in the polar stratosphere completely altered and columnar ozone changed. This study concentrated on the variability of winter polar vortex, meridional temperature gradient and associated changes in the Total Column Ozone (TCO) over the polar and middle latitude regions. It is found that changes in the amount of column ozone are positively correlated with polar lower stratospheric temperature with colder (warmer) temperature correlating with less (high) amount column ozone. But in the middle latitude region we observed negative correlations between ozone concentration and stratospheric temperature. In almost all cases there is sudden increase of ozone concentration over the pole and after few days the value is reduced when the warming effect is weak. During SSW events there observed an increase of 30 DU in TCO from the average value over the pole and if the SSW is strong TCO is found to rise by $50 \mathrm{DU}$. But in the middle latitude approximately $10 \mathrm{DU}$ increase is noted. From the above results it may be concluded that variability of column ozone depends on dynamic and stratospheric chemistry over the poles and in middle latitude the variability can be attributed to the dynamical aspects. Anomaly of column ozone is higher during sudden stratospheric warming events over both polar and middle latitude region. The meridional temperature gradient reverses first and after two days polar vortex changes its 
direction or weakens followed by an increase of column ozone over the polar region. An increase of $30^{\circ}$ Kelvin in the average temperature value noted over the polar region during sudden stratospheric warming events.

\author{
Keywords
}

\title{
Stratospheric Sudden Warming, Total Column Ozone, Polar Vortex
}

\section{Introduction}

Ozone plays a major role in the chemical and thermal balance of the atmosphere. Ozone was identified in the atmosphere by Schönbein in 1867 and soon corroborated by using chemical means [1] [2]. Atmospheric ozone is found in maximum at an altitude of $23-25 \mathrm{~km}$ in the equatorial stratosphere and varies with latitude and seasons. The British chemist Sydney Chapman proposed a cycle of chemical reactions driven by the sun as the mechanism for producing ozone layer in the stratosphere. Chapman showed that ozone $\left(\mathrm{O}_{3}\right)$ was created when oxygen atoms and oxygen molecules combine. The oxygen atoms are created when high-energy, ultraviolet light breaks up molecular oxygen $\left(\mathrm{O}_{2}\right)$. Atmospheric dynamics is known to be a major factor in the variability of stratospheric ozone distribution over the tropics from year to year. It is widely appreciated that the dynamics of the stratosphere is interrelated to a good extent with that of the troposphere [3] [4]. Thus transport and wind motion in the stratosphere are interconnected with those in the troposphere and thus play crucial roles in ozone distribution over the tropic. There is considerable evidence that the atmospheric total ozone amount is strongly influenced by the stratospheric circulation [5] [6]. Earlier works have consistently shown that good correlation exists between the total ozone amount and stratospheric geopotential heights, stratospheric temperature, and the tropopause height [7] [8].

The meridional transport in the winter stratosphere is largely controlled by large amplitude planetary waves. The most important of them are quasi-stationary Rossby waves that propagate upward from the troposphere and are quite strong and variable in winter [2]. Sudden stratospheric warming (SSWs) are the most important perturbing events that affect the dynamics and thermal structure of the winter stratosphere in the northern hemisphere. The Sudden Stratospheric Warming Phenomenon was first found over Berlin through the radio sounding observations in 1952 [9]. Stratospheric sudden warming is a breakdown event of the winter polar vortex associated with a sudden rise of temperature by several tens of Kelvin (K) in a few days in the polar stratosphere. Breaking and dissipation of westward propagating planetary waves at stratospheric altitude decelerate or even reverse the prevailing eastward flow of the polar wintertime stratosphere. The interaction of planetary waves and the zonal mean flow is known to be the major driver of winter stratospheric dynamics [2] [10]-[13]. The development of SSWs is linked to the vertical propagation of planetary waves, which dissipate first in the mesopshere and then progress through the stratosphere, interacting with the westerly winter circulation (polar vortex). Due to that interaction an upward and pole-ward directed heat and momentum flux lead to decreasing eastward winds and increasing temperature in the polar region [11] [14].

In a minor warming the temperature gradient reverses over a range of altitude at or below $10 \mathrm{hPa}$, but the zonal wind at $10 \mathrm{hPa}$ does not change its direction. Major SSWs as defined by the WMO occur on average every other year in the northern hemispheric winter [15] [16]. Sudden stratospheric warmings have been classified into vortex displacement events and vortex splitting events based on the shape and continuity of the polar vortex [15] [17]. The structure and dynamics of these "polar vortices" play a dominant role in the winter and spring stratospheric circulation and are key in determining distribution of trace gases, in particular ozone, and the couplings between the stratosphere and troposphere. Since polar vortices act as containment vessels and allow the occurrence of extremely low temperatures, they play a critical role in polar ozone depletion and the annual formation of the Antarctic ozone hole. Sudden stratospheric warming events have profound effects on the temperature, wind, and composition of the middle atmosphere. Sudden stratospheric warming influences the whole atmosphere and is essential for estimation of future ozone and temperature trends. It is basically a nonlinear dynamical event in planetary scale, while it is recognized as an event that has association with smaller spatial-scale gravity waves, and longer time-scale intra-seasonal and inter-annual variations or climate change of the polar vortex. 
Sudden stratospheric warming interacts with radiative and chemical processes in the stratosphere. During and after the SSW events, the enhanced residual circulations affect the chemical composition of the stratosphere as well as in the mesosphere and lower thermosphere (MLT). Observations have shown increased concentrations of $\mathrm{NO}, \mathrm{NO}_{2}, \mathrm{CO}, \mathrm{OH}$, and $\mathrm{O}$ in the MLT following the SSW of late winter 2004, 2006, and 2009 [18]-[21]. During the SSW events, dynamics, transport and evolution of the stratospheric chemical composition affect the middle atmosphere differently during Vortex splitting and vortex displacement SSWs events [15] [17] [22]-[24].

Minor events are less intense and do not produce the reversal of the mean zonal winter circulation of the polar stratosphere. The SSW occurs much more frequent, but for a still unexplained reason, only some of them have major impacts on the troposphere and our weather [25]. It is reported that the onset of SSW in the stratosphere, blocking of the synoptic scale wave patterns occurred leading to the advection of ozone rich, intensely cold arctic air into the eastern half of the United States. Recently major progress has been achieved in predicting major and minor SSWs at least 9 days in advance using the ensemble forecast data of Japan Meteorological Agency [26]. Simulations and observational studies indicated that sudden stratospheric warming is associated with mesospheric cooling and lower thermospheric warming [27]-[29].

The Arctic stratosphere is characterized by large inter-annual variation, with warm winters alternated with severe cold conditions. The large inter-annual variability makes the detection of trends in the Arctic winter extremely difficult [30]. Studies on polar vortex evolution and stratospheric warming can provide further insights on this issue. Studies have shown that these events have a strong impact on the background wind, temperature, ozone chemistry and wave activity in the middle and upper atmosphere, causing strong coupling over a large range of altitudes and latitudes [31]. Signature of high and low latitudinal coupling during a major sudden stratospheric warming in the tropics have been reported earlier [32] [33]. The occurrence of SSWs has been shown to be connected to the phase of the quasi-biennial oscillation, the solar cycle [34], and southern Oscillation [35]. The effect of a SSW on the ozone, hydroxyl distribution and water vapor in the mesopause region has been simulated [36]. The contributions of both chemistry and dynamics to polar vortex ozone at 24 - $36 \mathrm{~km}$ during the 2002-2003 SSW was quantified using measurements by the MIPAS instrument on board the Envisat satellite and the MOZART-3 chemical transport model [37]. In this paper five major SSWs events were considered to study the variability of total column ozone over the polar and middle latitude regions.

\section{Materials and Methods}

According to the definition by World Meteorological Organization (WMO) a major SSW at the 10-mbar level or below requires the two conditions namely 1) a latitudinal mean temperature increase towards poleward of 60 degree latitude and 2) an associated circulation reversal. In order to standardize the use of the terms "major” and “minor" stratospheric warming WMO Commission for Atmospheric Sciences has adopted the following definitions. A stratospheric warming is called major if at $10 \mathrm{hPa}$ or below the latitudinal mean temperature increases towards poleward from 60 degrees latitude and associated circulation change is observed (i.e. mean eastward winds of 60 degrees latitudes are turned to mean westward winds in the same area) [38]. Many have defined the SSW with slight variations such as the poleward temperature gradient must be at least four consecutive days [39] and others says that temperature gradient should be at least five days [13] in the same area. They also have taken the second criteria of mean zonal wind reversal about the 60 degrees latitude [15] is defined that the mean zonal winds must become westward at $60^{\circ}$ degree latitude but used the same but $60^{\circ} \mathrm{N}$ for the northern hemisphere [13]. During winter warming the day on which zonal mean zonal wind at $60^{\circ} \mathrm{N}$ becomes easterly at $10 \mathrm{hPa}$ is considered as the central date of warming [2]. Labitzke and Naujokat classified a SSW as a minor warming if there is a significant increase of temperature (at least by $25 \mathrm{~K}$ per week) below $10 \mathrm{hPa}$ levels in any area of the winter hemisphere [40].

To study the distribution of total column ozone during the SSW events, five SSWs events were identified based on the WMO definition (Table 1). The duration of SSW is taken as 20 days (10 days before and 10 days after the central date of warming events) for the study of polar vortex, temperature and column ozone over the Polar Cap $\left(60^{\circ} \mathrm{N}-90^{\circ} \mathrm{N}\right.$ Latitude \& $0^{\circ}-360^{\circ}$ Longitude) and Middle Latitude region $\left(30^{\circ} \mathrm{N}-60^{\circ} \mathrm{N}\right.$ Latitude \& $0^{\circ}$ - 360 ${ }^{\circ}$ Longitude). Daily wind and temperature with a grid resolution of $2.5 \times 2.5$ were taken from the National Centers for Environmental Prediction/National Center for Atmospheric Research (NCEP/NCAR) reanalysis and daily column ozone is taken from the NCEP 20th Century reanalysis with same grid resolution as that of the zonal wind and temperature. A complete description of the NCEP/NCAR reanalysis data has been described elsewhere [41]. 
Table 1. Sudden stratospheric warming events and associated ozone and temperature changes.

\begin{tabular}{ccccccccc}
\hline Sl. No & Year of SSW & $\begin{array}{c}\text { Central date of } \\
\text { warming }\end{array}$ & $\begin{array}{c}\text { Duration of } \\
\text { SSW (days) }\end{array}$ & $\begin{array}{c}\text { T min } \\
\text { anomaly }\end{array}$ & $\begin{array}{c}\text { T max } \\
\text { anomaly (K) }\end{array}$ & $\begin{array}{c}\text { Ozone before } \\
\text { SSW (DU) }\end{array}$ & $\begin{array}{c}\text { Ozone during } \\
\text { SSW (DU) }\end{array}$ & $\begin{array}{c}\text { Range of } \mathbf{O}_{3} \\
\text { in SSW }\end{array}$ \\
\hline 1 & $1998-99$ & 14 Dec-98 & 10 & $-12 \mathrm{~K}$ & $15 \mathrm{~K}$ & $-15 \mathrm{DU}$ & $10 \mathrm{DU}$ & $25 \mathrm{DU}$ \\
2 & $1987-88$ & $7 \mathrm{Dec}-87$ & 13 & $-18 \mathrm{~K}$ & $15 \mathrm{~K}$ & $-20 \mathrm{DU}$ & $10 \mathrm{DU}$ & $30 \mathrm{DU}$ \\
3 & $1984-85$ & $29 \mathrm{Dec}-84$ & 13 & $-12 \mathrm{~K}$ & $12 \mathrm{~K}$ & $0 \mathrm{DU}$ & $10 \mathrm{DU}$ & $10 \mathrm{DU}$ \\
4 & $1981-82$ & $2 \mathrm{Dec}-81$ & 9 & $-3 \mathrm{~K}$ & $3 \mathrm{~K}$ & $-10 \mathrm{DU}$ & $10 \mathrm{DU}$ & $30 \mathrm{DU}$ \\
5 & $1980-81$ & 28 Feb-80 & 5 & $-9 \mathrm{~K}$ & $12 \mathrm{~K}$ & $-40 \mathrm{DU}$ & $40 \mathrm{DU}$ & $80 \mathrm{DU}$ \\
\hline
\end{tabular}

\section{Results and Discussions}

Occurrence of SSW in winter is part of the reason why there is no strong ozone hole forming over the Arctic as there is one over the Antarctic. In fact, strong mixing of polar and low latitude air together with the temperature increase during a SSW prevents the development of very low temperatures and the buildup of a strong and isolated polar vortex. Hence polar stratospheric clouds (PSCs) responsible for considerable ozone destruction are less abundant in the Arctic winter than in the Antarctic and PSCs at middle latitudes are unusual. Extreme winter stratosphere leads to an increasing volume of air cold enough for the occurrence of PSCs, which in turn leads to more ozone loss inside the polar vortex [42]. Reactions occur on the surface of PSC particles that convert the reservoir forms of chlorine gases, $\mathrm{ClONO}_{2}$ and $\mathrm{HCL}$, to reactive forms, such as $\mathrm{ClO}$, which lead to catalytic ozone destruction when sunlight is available. Large PSC particles may move $\mathrm{HNO}_{3}$ from regions of the ozone layer. With less $\mathrm{HNO}_{3}$, the highly reactive CLO remains chemically active for a long period, thereby increasing chemical ozone destruction [43]. Sudden stratospheric warming usually occurs over the Northern polar stratosphere since planetary wave activity is generated due to the topographic and thermal feature of Northern hemisphere. But in contrary to our understanding the first ever detection of a major SSW in the Southern Hemisphere (SH) occurred during 2002 Antarctic winter [44]-[46].

The distribution of ozone is affected by changes in both chemistry and dynamics during the SSW events over the Northern Hemisphere. The short-term changes in stratospheric ozone in response to SSWs have been rather extensively studied using ground-based, in situ and satellite observations [37] [47]-[50]. In this paper the response of the TCO with five different SSWs events were considered to understand the variation of total column ozone over the polar and middle latitude region of the Northern hemisphere.

\subsection{Evolution of Polar Vortex and Meridional Temperature Gradient during SSW}

Figure 1 and Figure 2 show the evolution global average anomalies of meridional temperature gradient and mean zonal wind over the polar stratosphere $\left(60^{\circ} \mathrm{N}-90^{\circ} \mathrm{N}\right)$ at 10 hpa during the five different years of (1998-99, 1987-88, 1984-85, 1981-92 and 1979-80) SSW events respectively from the top to bottom panel. All four cases of major warming occurred during the month of December out of five SSWs cases selected and in only one case it occurred at the end of late February, which can be treated as the final warming, since any more warming is not possible in the winter during that year. Individual cases of warming condition, strength of polar vortex and duration of warming days are different for different SSW cases. In all cases temperature gradient and zonal wind reversal begin at $10 \mathrm{hPa}$ level from $60^{\circ}$ north and slowly propagate the trend to the Polar Regions (WMO definition for SWW events) and reaches to poles after few days. Also there is a lag of 2 days between temperature gradient and wind reverse during all the SSW events except one year (SSW 1987-88). In the present study two SSW (SSW 1987-88 and SSW 1981-80) cases showed very weak meridional temperature gradient (Figure 1) but the polar vortex strength does not affected (Figure 2). In the entire cases polar vortex anomaly reached a magnitude of $-30 \mathrm{~ms}^{-1}$ during the SSW events. There is clear evidence of zonal wind reversals which begins from $60^{\circ} \mathrm{N}$ and reaches at the poles. These dynamic behaviors of SSW which alter the chemical and dynamical structure of the stratosphere at $10 \mathrm{hPa}$ affect the distribution of total column ozone concentration over the northern polar region. The date on which the polar vortex changes its direction (from westerly to easterly) is considered as the central date of stratospheric warming (see Table 1). The meridional temperature gradient shows a time lag of few days to reach the poles (in Figure 1. SSW 1998-99 and SSW 1979-80), but polar vortex does not show any time lag in changing its direction (Figure 2). 


\subsection{Evolution of Columnar Ozone over the Northern Polar Region during SSWs}

Figures 3-5 represent the reversal of temperature gradient $(\mathrm{K})$, polar vortex evolution (m/s), and associated distribution of column ozone anomaly (DU) over the polar region $\left(60^{\circ} \mathrm{N}-90^{\circ} \mathrm{N}\right.$ and $0-360$ longitude) during five SSW events. In Figure 4 the central date of warming is clearly seen as the date of reversal of polar vortex direction. In few cases of SSW events (e.g. 1998-99, 1987-88, 1984-85, and 1979-80), polar vortex is strong enough not to permit the ozone rich air from mid-latitude to mix with polar ozone. Normally in winter the very cold $\left(-80^{\circ} \mathrm{C}\right)$ stratosphere with strong polar vortex (westerly wind) support the formation of polar stratospheric clouds (PSC), which serve the surface to enhance the heterogeneous photochemical catalytic depletion of ozone. But during SSW years, formation PSC is not happening over the poles, instead the sudden increase in temperature enhances the photochemical production of ozone over the polar stratosphere. Minor warming occurs every

Temperature(K) anomaly during winter SSW at $10-\mathrm{hPa}$
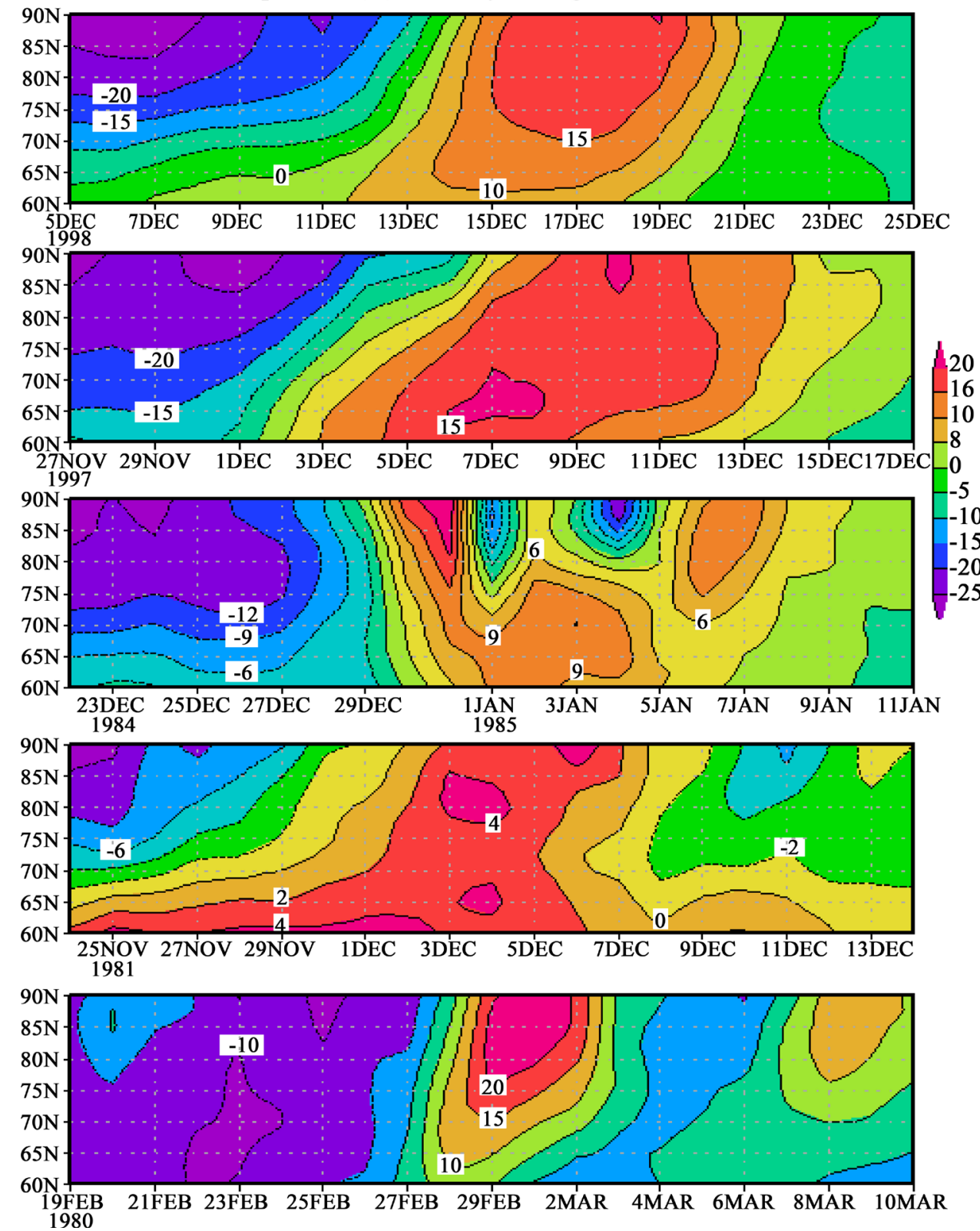

Figure 1. Meridional gradient of temperature (K) anomaly during five cases of SSW events (1998-99, 1987-88, 1984-85, 1981-82 and 1979-80). 


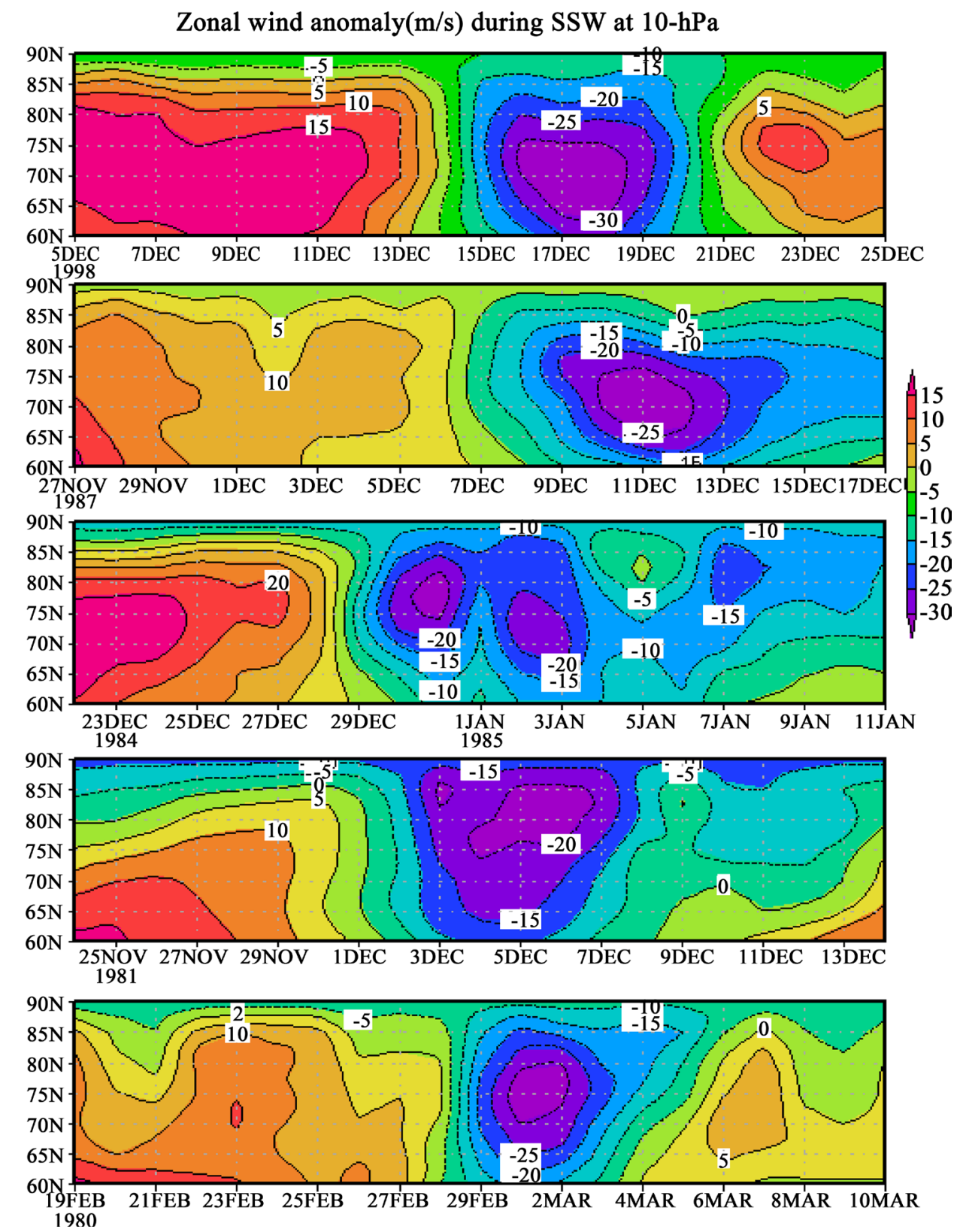

Figure 2. Evolution of polar vortex during five cases of SSW events (1998-99, 1987-88, 1984-85, 1981-82 and 1979-80).

year in the polar stratosphere, but some time major warming also happens. If the major warming occur in the middle of the winter, after a few days (may be after one week) the stratosphere restore its winter characteristics. But if the warming occurs at the end of the winter season, there is no possibility of another warming event in the same year since the stratosphere already entered to the summer season. From Figure 3 and Figure 4, it is seen that four cases of warming occurred during the month of December except in the year 1979-80, which is called a final warming. Figure 5 represent the column ozone concentration during different selected SSWs years. Table 1 gives the summary of changes in total ozone concentration and temperature during different years of sudden stratospheric warming events. An increasing trend of total ozone concentration during SSW period is observed over the polar region. The date of warming is taken as the date on which polar vortex reverse its direction due to meridional temperature gradient. Sudden stratospheric warming anomaly of zonal wind $\left(\mathrm{ms}^{-1}\right)$, temperature $\left({ }^{\circ} \mathrm{K}\right)$ and column ozone (DU) at 10 hPa over a polar region (60 - 90 Latitude \& 0 - 360 Longitude) were calculated. The duration of warming is taken as 20 days from the central date of warming (10 days before and after the cen- 
tral date of warming) based on the particular month of occurrence of SSW averaged (mean value) and then subtracted the mean from the daily values of zonal wind, temperature and TCO for 20 days. For every SSW events there is an increase of $30 \mathrm{DU}$ in the average value of TCO over the poles. During final warming of SSW a great variation of $80 \mathrm{DU}$ is noted in the total column ozone amount (Table 1). From this analysis it is clearly understood that TCO variations strongly depends on the evolution of polar stratospheric chemistry and dynamics during SSWs events. This increase in ozone concentrations reveals that heterogeneous catalytic depletion of ozone is hampered during the SSW events due to the reversal of the meridional temperature gradient (PSC does not form over polar stratosphere) and changes in the polar dynamics (reversal of polar vortex). Studies show that in

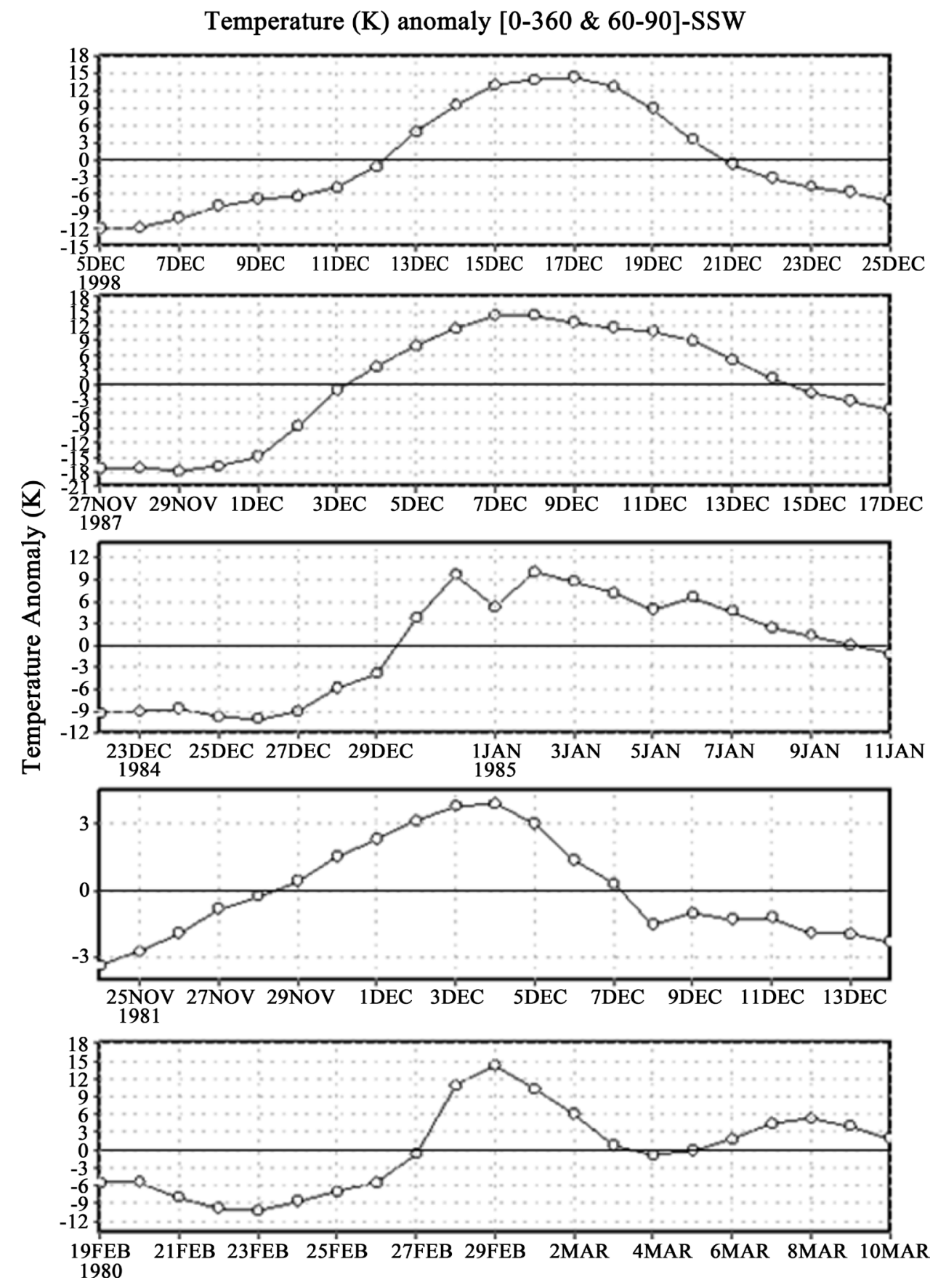

Figure 3. Meridional gradient of temperature anomaly (K) over the polar region during the of SSW events (1998-99, 1987-88, 1984-85, 1981-82 and 1979-80). 

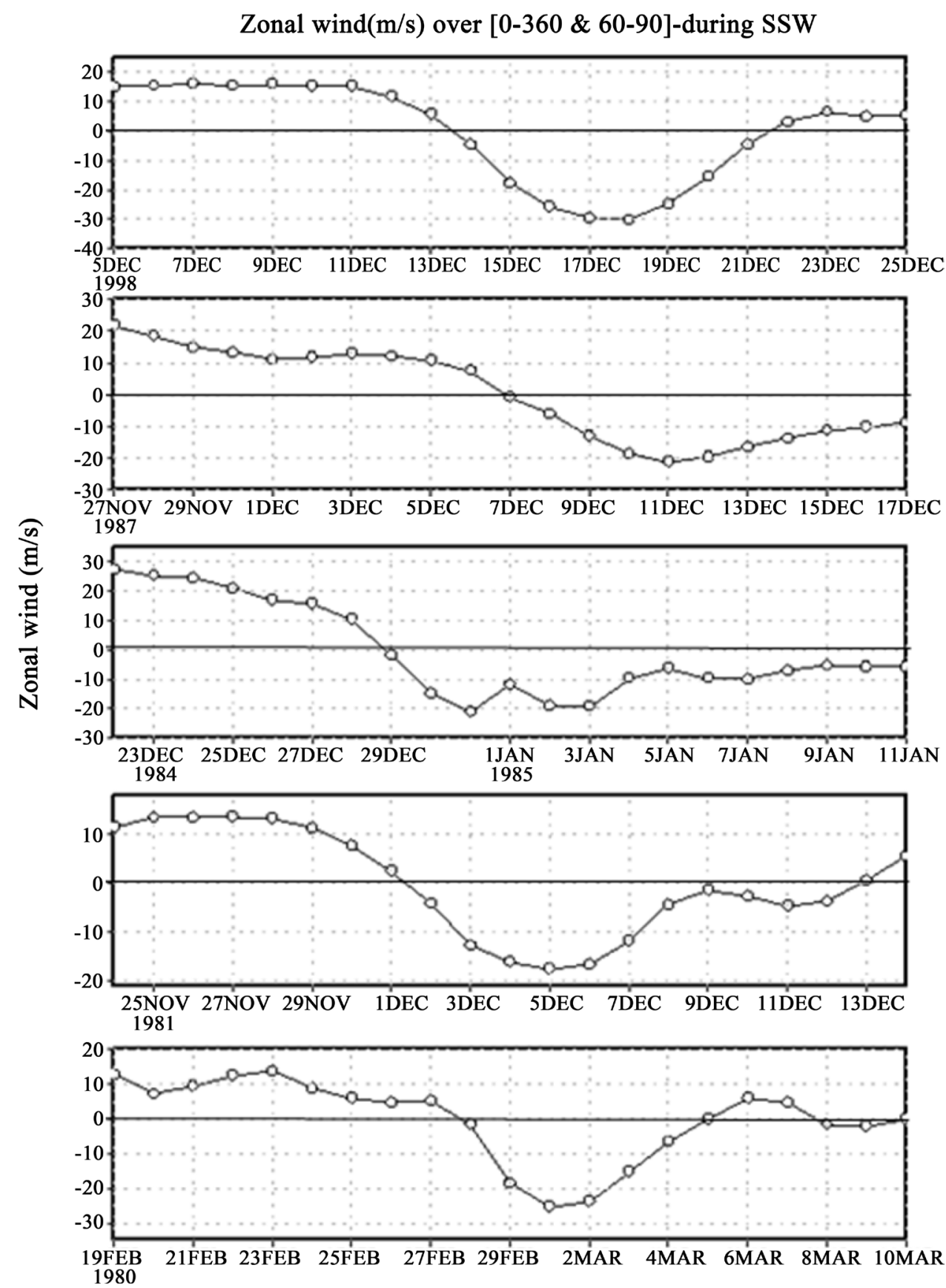

Figure 4. Zonal wind anomaly (m/s) at $10 \mathrm{hPa}$ during SSW events (1998-99, 1987-88, 1984-85, 1981-82 and 1979-80).

the ozone budget analysis ozone is enhanced by 26 - 28 DU inside the polar vortex due to the SSW [37]. In this paper, analysis and observations support the previous work on the variability of ozone concentration during SSWs days.

\subsection{TCO Distribution over Middle Latitude Region during SSW}

Even though SSWs events occur over the polar stratosphere, various studies shows the coupling between low and high latitudes and the changes in dynamics and chemical composition of the atmosphere with latitudes [51]. The vertical layers of the atmosphere are coupled during the occurrence of SSW in the polar stratosphere and thereby affect the chemical composition and dynamics of the layers below and above the stratosphere. It is 

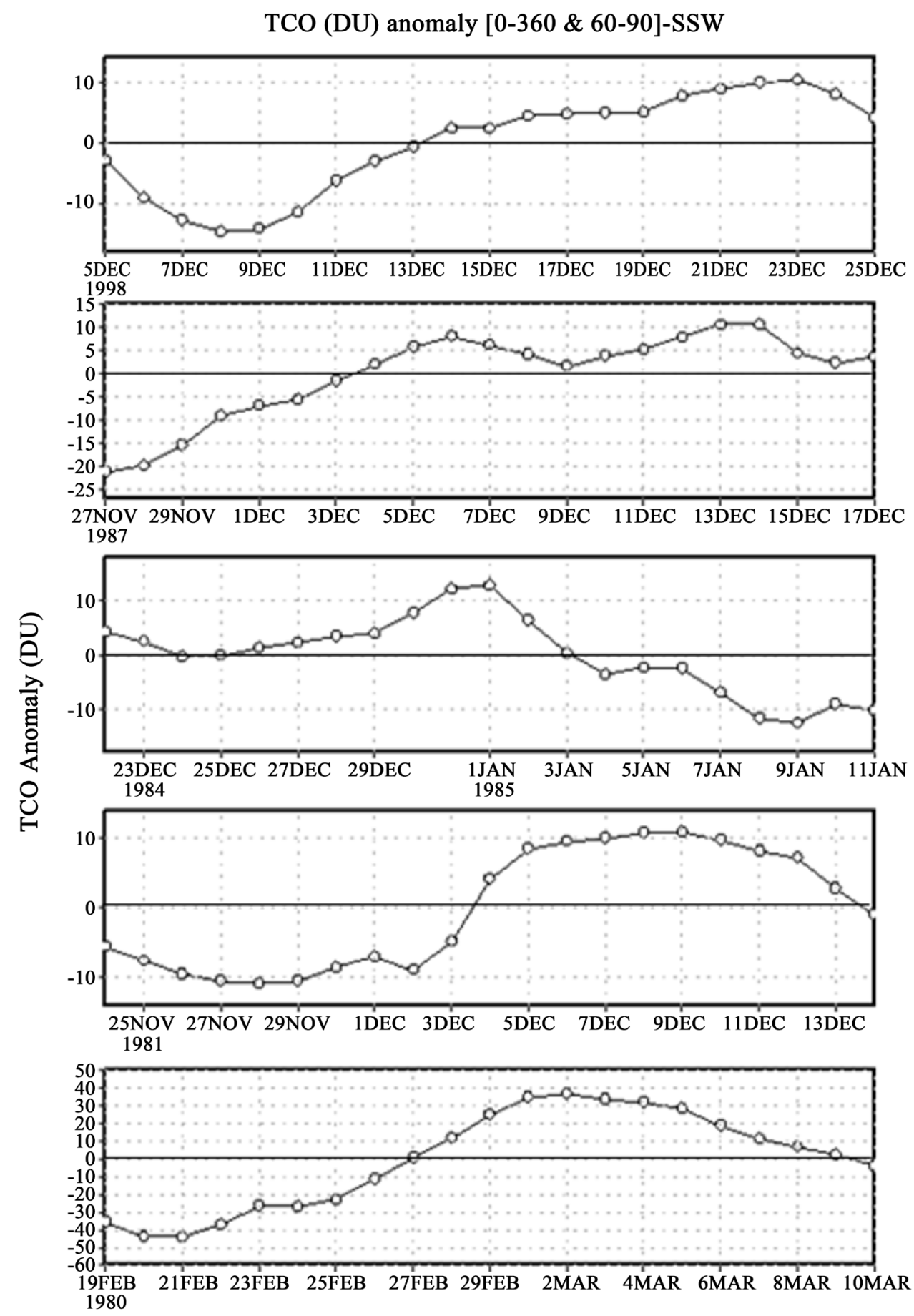

Figure 5. TCO anomaly (DU) over polar region during SSW events (1998-99, 1987-88, 1984-85, 1981-82 and 1979-80).

known that SSWs are accompanied with a cooling in the mesosphere [11]. The variability of mesospheric tides during the SSW events and associated changes in ozone and water vapor has been reported earlier [52]. It was also reported that SSWs causes anomalous weather regimes 60 days after in the troposphere [53].

Figure 6 and Figure 7 represent the temperature and column ozone anomaly over the middle latitude region $\left(30^{\circ} \mathrm{N}-60^{\circ} \mathrm{N}\right.$ and $0-360$ longitudes) during the SSWs events. As we know the meriodional temperature gradient reverses during SSW events and polar stratosphere experiences a high temperature and middle latitude experience a low temperature. The reversal of temperature is opposite in the middle latitude region, i.e., positive 
value to negative temperature anomaly observed during SSWs events. But in Figure 7 the total column ozone shows opposite relation with middle latitude temperature variability. Here increase of temperature give the decrease of total column ozone value and vice versa (see Figure 6 and Figure 7). The polar ozone concentration depends both on dynamics and winter polar stratospheric chemistry. That is polar vortex changes due to the interaction of planetary waves with mean flow and the reversal of meriodional temperature gradient. As a result ozone loss due to catalytic heterogeneous photochemical reaction is suppressed in the absence of Polar Stratospheric Clouds (PSC) during SSWs. But in the middle latitude ozone loss due to catalytic heterogeneous

Temperature (K) anomaly $[0-360 \& 60-90]-\mathrm{SSW}$

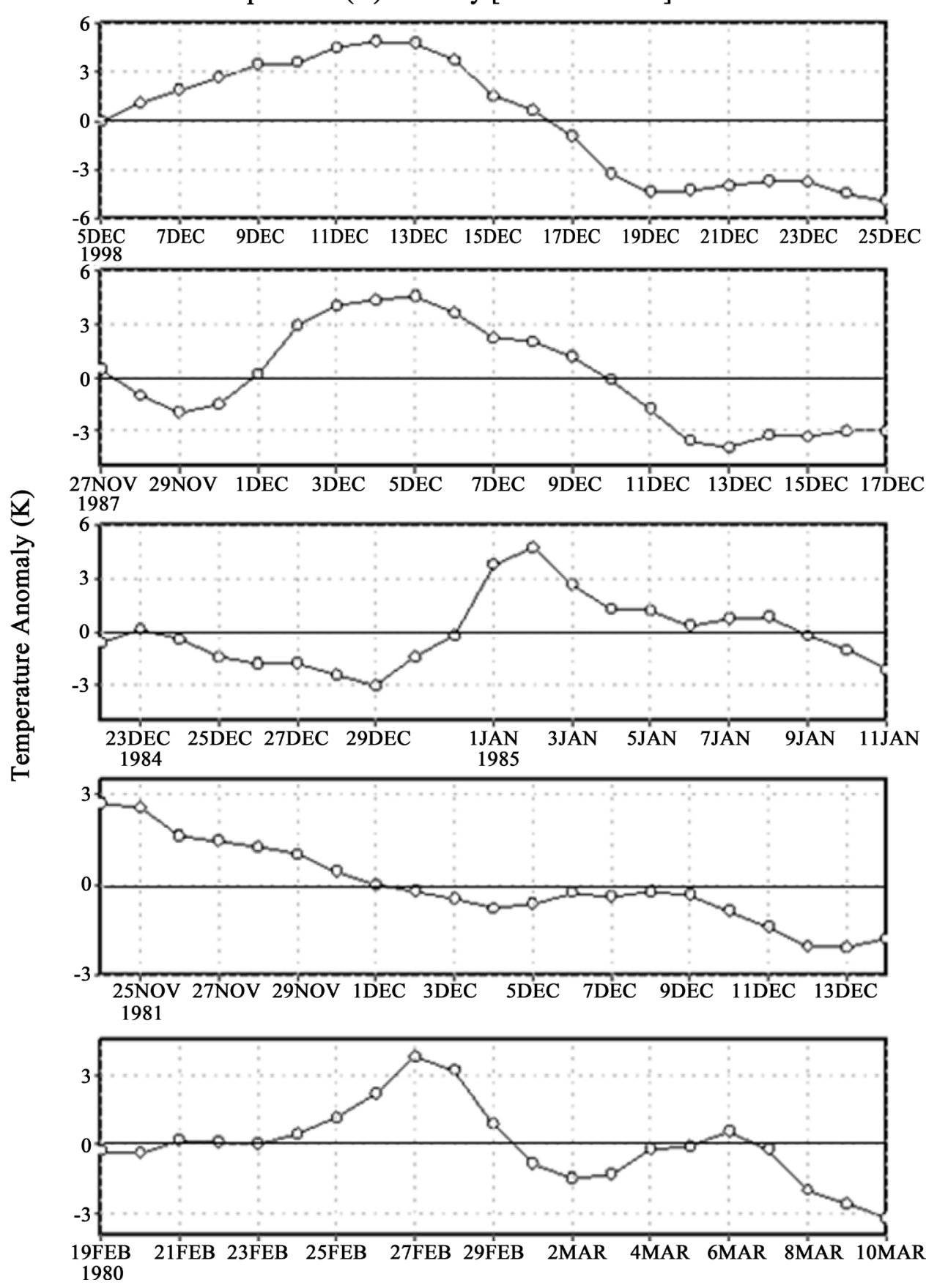

Figure 6. Meridional gradient of temperature anomaly $(\mathrm{K})$ over the middle latitude region during the of SSW events (1998-99, 1987-88, 1984-85, 1981-82 and 1979-80). 


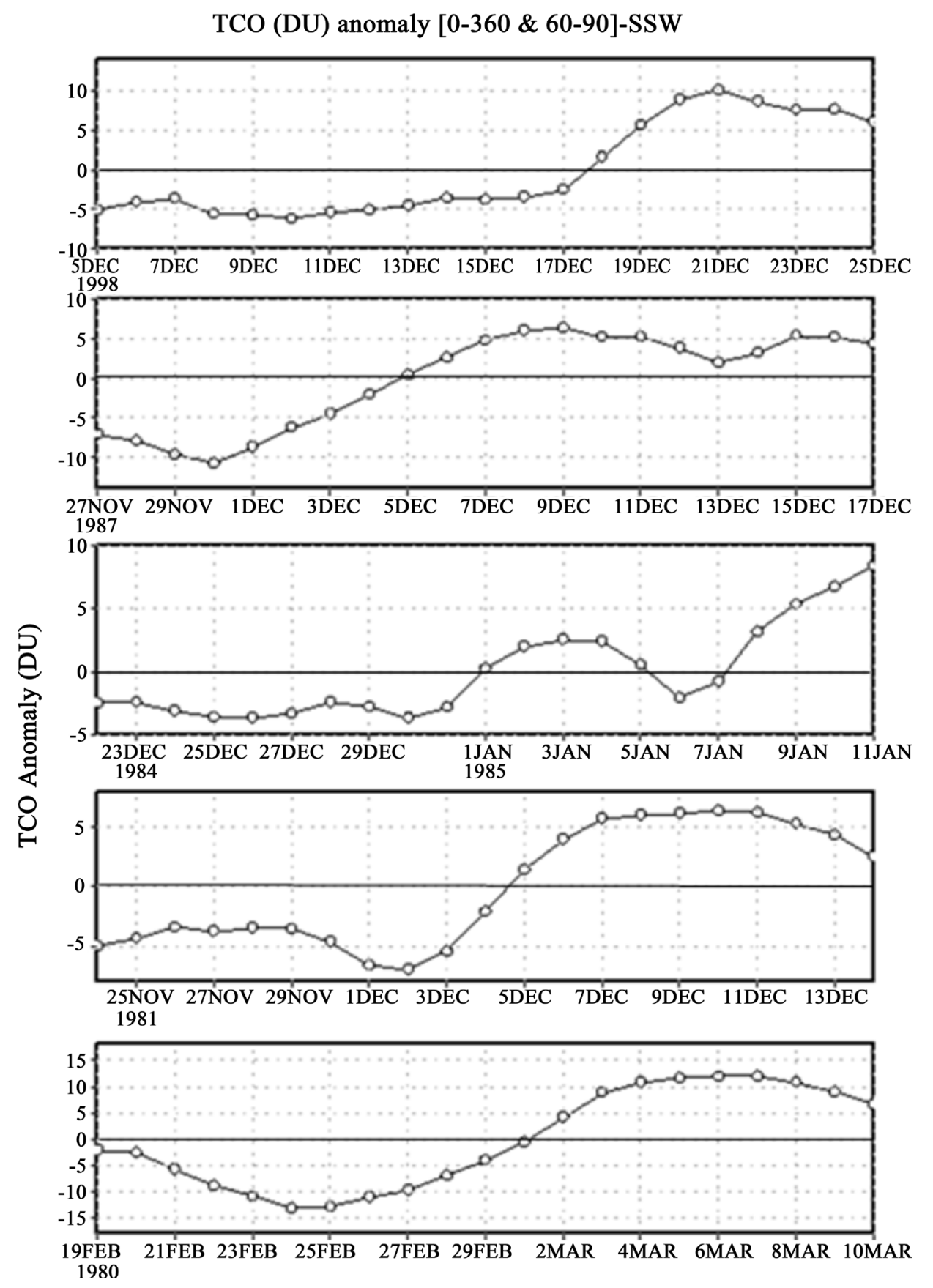

Figure 7. TCO anomaly (DU) over middle latitude region during SSW events (1998-99, 1987-88, 1984-85, 1981-82 and 1979-80).

photochemical reactions are very less and hence the variability depends on the dynamical reasons rather than photochemical reactions. In the middle latitude region the approximate increase of ozone is about 5 to 20 DU during the SSW events. But in the polar region an approximate increase of about 30 DU to 50 DU and more are observed during very strong stratospheric warming events with very short duration (e.g. SSW 1980-81). Figure 8 represent the correlation value of column ozone with temperature over the polar and middle latitude region for 20 days (10 days before and after the central date of warming). From Figure 8, it is clearly seen that a very strong positive correlation exists between total column ozone and temperature over the polar region whereas a negative correlation exists in the middle latitude region. 


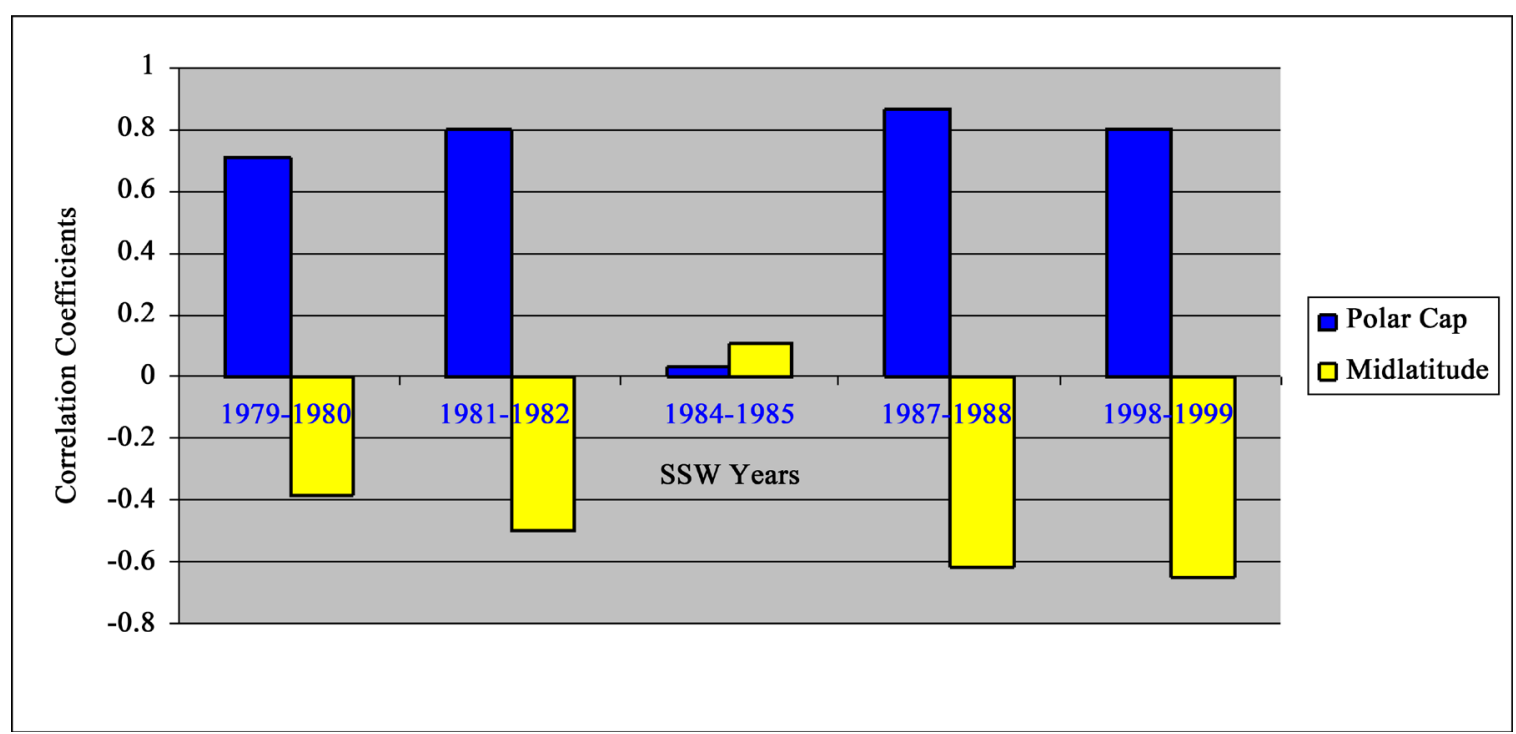

Figure 8. Correlation coefficient of temperature and column ozone over the polar and middle latitude region during SSW events (1998-99, 1987-88, 1984-85, 1981-82 and 1979-80).

\section{Summary and Conclusion}

In this study, the variation of total ozone concentration during five SSWs cases (1998-99, 1987-88, 1984-85, 1981-82 and 1979-80) was analyzed over the polar and middle latitude regions. Warming in the polar stratosphere occurred in the mid-winter resulted in an increase of $30 \mathrm{DU}$ in the TCO mean value. On the other hand the final stratospheric warming, which occurred in the late winter (e.g. SSW 1979-80) shows grater values of TCO variation (greater than $50 \mathrm{DU}$ ). But in the middle latitude region the variability of TCO is about $10 \mathrm{DU}$ from the mean value and this may be attributed to dynamical reasons than the chemical aspects. Total ozone concentration increases over the polar region with a lag of 2 days after the reversal of the meridional temperature gradient. Total column ozone shows a positive correlation with the temperature at the polar region and a negative correlation over the middle latitude region. From the analysis it may be concluded that the variability in ozone concentration over the polar region is connected with dynamical behavior and heterogeneous photochemistry. But in middle latitude region ozone variation may be due to dynamical changes than due to other factors. The impact of SSW is very important and it alters the chemical and dynamical characteristics of the polar weather and it also modifies the low latitude weather systems through high and low latitude interactions.

\section{Acknowledgements}

Author is thankful to the Indian Space Research Organization (ISRO)—Respond Project scheme and Science an Engineering Research Board (SERB)—Department of Science and Technology (DST), Government of India for funding the project. Also acknowledges two anonymous reviewers.

\section{References}

[1] Rubin, M.B. (2001) The History of Ozone; the Schönbein Period, 1839-1868. Bulletin for the History of Chemistry, 26, 40-56.

[2] Andrews, D.G., Holton, J.R. and Leovy, C.B. (1987) Middle Atmosphere Dynamics. Academic Press Inc., 491 p.

[3] Randel, W.J. (1988) The Seasonal Evolution of Planetary Waves in the Southern Hemisphere Stratosphere and Troposphere. Quarterly Journal of the Royal Meteorological Society, 114, 1385-1409. http://dx.doi.org/10.1002/qj.49711448403

[4] Holton, J.R., Haynes, P.H., McyInty, M.E., Douglas, A.R., Rood, R.B. and Pfister, L. (1995) Stratosphere Troposphere Exchange. Review of Geophysics, 33, 403-439. http://dx.doi.org/10.1029/95RG02097

[5] Ghazi, A. (1974) Nimbus 4 Observations of Changes in Total Ozone and Stratospheric Temperature during a Sudden Warming. Journal of the Atmospheric Sciences, 31, 2197-2206. 
http://dx.doi.org/10.1175/1520-0469(1974)031<2197:NOOCIT>2.0.CO;2

[6] Kulakarni, R.N. (1979) Ozone Trend and the Stratospheric Circulation over Australia. Quarterly Journal of the Royal Meteorological Society, 102, 697-704. http://dx.doi.org/10.1002/qj.49710243314

[7] Meetham, A.R. (1937) The Correlation of the Amount of Ozone with Other Characteristics of the Atmosphere. Quarterly Journal of the Royal Meteorological Society, 81, 262-264. http://dx.doi.org/10.1002/qj.49706327102

[8] Frit, Z.S. and Stevens, G.C. (1950) Atmospheric Ozone at Washington, D.C. Monthly Weather Review, 78, $135-147$. http://dx.doi.org/10.1175/1520-0493(1950)078<0135:AOAWDC>2.0.CO;2

[9] Scherhag, R. (1952) Die explosionsartigen Stratospherenerwarmingen des Spatwinters, 1951-1952. Ber. Deut. Wetterd. (U.S. Zone), 6, 51-63.

[10] Matsuno, T. (1970) Vertical Propagation of Stationary Planetary Waves in the Winter Northern Hemisphere. Journal of the Atmospheric Sciences, 37, 871-883. http://dx.doi.org/10.1175/1520-0469(1970)027<0871:VPOSPW>2.0.CO;2

[11] Matsuno, T. (1971) A Dynamical Model of the Stratospheric Sudden Warming. Journal of the Atmospheric Sciences, 28, 1479-1494. http://dx.doi.org/10.1175/1520-0469(1971)028<1479:ADMOTS>2.0.CO;2

[12] Labitzke, K. (1981) Stratospheric-Mesospheric Midwinter Disturbances: A Summary of Observed Characteristics. Journal of Geophysical Research, 86, 9665-9678. http://dx.doi.org/10.1029/JC086iC10p09665

[13] Limpasuvan, V., Thompson, D.W.J. and Hartmann, D.L. (2004) The Life Cycle of the Northern Hemisphere Sudden Stratospheric Warmings. Journal of Climate, 17, 2584-2596. http://dx.doi.org/10.1175/1520-0442(2004)017<2584:TLCOTN>2.0.CO;2

[14] Hoffmann, P., Singer, W. and Keuer, D. (2002) Variability of the Mesospheric Wind Field at Middle and Arctic Latitude in Winter and Its Relation to Stratospheric Circulation Disturbances. Journal of Atmospheric and Solar-Terrestrial Physics, 64, 1229-1240. http://dx.doi.org/10.1016/S1364-6826(02)00071-8

[15] Charlton, A.J. and Polvani, L.M. (2007) A New Look at Stratospheric Sudden Warmings: Part I. Climatology and Modeling Benchmarks. Journal of Climate, 20, 449-469. http://dx.doi.org/10.1175/JCLI3996.1

[16] De la Torre, L., Garcia, R.R., Barriopedro, D. and Chandran, A. (2012) Climatology and Characteristics of Stratospheric Sudden Warmings in the Whole Atmosphere Community Climate Model. Journal of Geophysical Research, 117, D04110. http://dx.doi.org/10.1029/2011jd016840

[17] Matthewman, N.J., Esler, J.G., Charlton-Perez, A.J. and Polvani, L.M. (2009) A New Look at Stratospheric Sudden Warmings. Part III: Polar Vortex Evolution and Vertical Structure. Journal of Climate, 22, 1566-1585. http://dx.doi.org/10.1175/2008JCLI2365.1

[18] Randall, C.E., Harvey, V.L., Singleton, C.S., Bernath, P.F., Boone, C.D. and Kozyra, J.U. (2006) Enhanced NOx in 2006 Linked to Strong Upper Stratospheric Arctic Vortex. Geophysical Research Letters, 33, L18811. http://dx.doi.org/10.1029/2006GL027160

[19] Randall, C.E., Harvey, V.L., Siskind, D.E., France, J., Bernath, P.F., Boone, C.D. and Walker, K.A. (2009) NO x Descent in the Arctic Middle Atmosphere in Early 2009. Geophysical Research Letters, 36, L18811. http://dx.doi.org/10.1029/2009GL039706

[20] Orsolini, Y.J., Urban, J., Murtagh, D.P., Lossow, S. and Limpasuvan, V. (2010) Descent from the Polar Mesosphere and Anomalously High Stratopause Observed in 8 Years of Water Vapor and Temperature Satellite Observations by the Odin Sub-Millimeter Radiometer. Journal of Geophysical Research, 115, D12305. http://dx.doi.org/10.1029/2009jd013501

[21] Kvissel, O.-K., Orsolini, Y.J., Stordal, F., Limpasuvan, V., Richter, J.H. and Marsh, D.R. (2012) Mesospheric Intrusion and Anomalous Chemistry during and after a Major Stratospheric Sudden Warming. Journal of Atmospheric and Solar-Terrestrial Physics, 78-79, 116-124. http://dx.doi.org/10.1016/j.jastp.2011.08.015

[22] Manney, G.L., Kruger, K., Sabutis, J.L., Sena, S.A. and Pawson, S. (2005) The Remarkable2 2003-2004 Winter and Other Recent Warm Winters in Arctic Stratosphere since 1990s. Journal of Geophysical Research, 110, D04107. http://dx.doi.org/10.1029/2004JD005367

[23] Shepherd, T.G. (2007) Transport in the Middle Atmosphere. Journal of the Meteorological Society of Japan, 85B, 165-191. http://dx.doi.org/10.2151/jmsj.85B.165

[24] Holt, L.A., Randall, C.E., Peck, E.D., Marsh, D.R., Smith, A.K. and Harvey, V.L. (2013) The Influence of Major Sudden Stratospheric Warming and Elevated Stratopause Events on the Effects of Energetic Particle Precipitation in WACCM. Journal of Geophysical Research: Atmospheres, 118, 11,636-11,646. http://dx.doi.org/10.1002/2013JD020294

[25] Quiroz, R.S. (1977) The Tropospheric-Stratospheric Polar Vortex Breakdown of January 1977. Geophysical Research Letters, 4, 151-154. http://dx.doi.org/10.1029/GL004i004p00151

[26] Hirooka, T., Ichimaru, T. and Mukougawa, H. (2007) Predictability of Stratospheric Sudden Warming as Inferred from 
Ensemble Forecast Data: Intercomparison of 2001/02 and 2003/04 Winters. Journal of the Meteorological Society of Japan, 85, 919-925. http://dx.doi.org/10.2151/jmsj.85.919

[27] Liu, H.-L. and Roble, R.G. (2002) A Study of Self-Generated Stratospheric Sudden Warming and Its Mesospheric-Lower Thermospheric Impacts Using the Coupled TIME-GCM/CCM3. Journal of Geophysical Research, 107, 4695. http://dx.doi.org/10.1029/2001jd001533

[28] Siskind, D.E., Coy, L. and Espy, P. (2005) Observations of Stratospheric Warming and Mesospheric Coolings by the TIMED SABER Instrument. Geophysical Research Letters, 32, L09804. http://dx.doi.org/10.1029/2005gl022399

[29] Hoffmann, P., Singer, W., Keuer, D., Hocking, W.K., Kunze, M. and Murayama, Y. (2007) Latitudinal and Longitudinal Variability of Mesospheric Winds and Temperatures during Stratospheric Warming Events. Journal of Atmospheric and Solar-Terrestrial Physics, 69, 2355-2366. http://dx.doi.org/10.1016/j.jastp.2007.06.010

[30] Manney, G.L., Schwartz, M.J., Krüger, K., Santee, M.L., Pawson, S., Lee, J.N., Daffer, W.H., Fuller, R.A. and Livesey, N.J. (2009) Aura Microwave Limb Sounder Observations of Dynamics and Transport during the Record-Breaking 2009 Arctic Stratospheric Major Warming. Geophysical Research Letters, 36, L12815. http://dx.doi.org/10.1029/2009gl038586

[31] Goncharenko, L. and Zhang, S.-R. (2008) Ionospheric Signatures of Sudden Stratospheric Warming: Ion Temperature at Middle Latitude. Geophysical Research Letters, 35, L21103. http://dx.doi.org/10.1029/2008gl035684

[32] Guharay, A. and Sekar, R. (2011) Signature of Latitudinal Coupling during a Major Sudden Stratospheric Warming in the Tropics. Journal of Atmospheric and Solar-Terrestrial Physics, 75-76, 122-126.

[33] Chau, J.L., Fejer, B.G. and Goncharenko, L.P. (2009) Quiet Variability of Equatorial E X B Drifts during a Sudden Stratospheric Warming Event. Geophysical Research Letters, 36, L05101.

Fabry, C. and Buisson, H. (1913) L'absorption de l'ultraviolet par l'ozone et la limite du spectre solaire. Journal de Physique et Le Radium, 3, 196-206.

[34] Labitzke, K. and van Loon, H. (1988) Association between the 11-Year Solar Cycle, the QBO and the Atmosphere, Part I: The Troposphere and the Stratosphere in the Northern Winter. Journal of Atmospheric and Solar-Terrestrial Physics, 50, 197-206. http://dx.doi.org/10.1016/0021-9169(88)90068-2

[35] van Loon, H. and Labitzke, K. (1987) The Southern Oscillation, Part V: The Anomalies in the Lower Stratosphere of the Northern Hemisphere in Winter and a Comparison with the Quasi-Biennal Oscillation. Monthly Weather Review, 115, 357-369. http://dx.doi.org/10.1175/1520-0493(1987)115<0357:TSOPVT>2.0.CO;2

[36] Sonnemann, G.R., Grygalashvyly, M. and Berger, U. (2006) Impact of a Stratospheric Warming Event in January 2001 on the Minor Constituents in the MLT Region Calculated on the Basis of a New 3D-Model LIMA of the Dynamics and Chemistry of the Middle Atmosphere. Journal of Atmospheric and Solar-Terrestrial Physics, 68, 2012-2025. http://dx.doi.org/10.1016/j.jastp.2006.04.005

[37] Liu, Y., Liu, C., Tie, X. and Gao, S. (2011) Middle Stratospheric Polar Vortex Ozone Budget during the Warming Arctic Winter, 2002-2003. Advances in Atmospheric Sciences, 28, 985-996. http://dx.doi.org/10.1007/s00376-010-0045-9

[38] McInturff, R. (1978) Stratospheric Warmings: Synoptic, Dynamical and General-Circulation Aspects. NASA Reference Publication, NASA-RP-1017, NASA, National Meteorological Center, Washington DC.

[39] Chaffey, J. and Fyfe, J. (2001) Arctic Polar Vortex Variability in the Canadian Middle Atmosphere Model. Atmosphere-Ocean, 39, 457-469. http://dx.doi.org/10.1080/07055900.2001.9649688

[40] Labitzke, K. and Naujokat, B. (2000) The Lower Arctic Stratosphere in Winter since 1952. SPARC Newsletter, 15, 11-14.

[41] Kalnay, E., Kanamitsu, M., Kistler, R., Collins, W., Deaven, D., Gandin, L., et al. (1996) The NCEP/NCAR 40-Year Reanalysis Project. Bulletin of the American Meteorological Society, 77, 437-471. http://dx.doi.org/10.1175/1520-0477(1996)077<0437:TNYRP>2.0.CO;2

[42] Rex, M., Salawitch, R.J., Deckelmann, H., von der Gathen, P., Harris, N.R.P., Chipperfield, M.P., et al. (2006) Arctic Winter 2005: Implications for Stratospheric Ozone Loss and Climate Change. Geophysical Research Letters, 33, L23808. http://dx.doi.org/10.1029/2006gl026731

[43] Crutzen, P.J. and Amold, F. (1986) Nitric Acid Cloud Formation in the Cold Antarctic Stratosphere-A Major Cause for the Springtime “Ozone Hole”. Nature, 324, 651-655. http://dx.doi.org/10.1038/324651a0

[44] Baldwin, M., Hirooka, T., O’Neill, A. and Yoden, S. (2003) Major Stratospheric Warming in the Southern Hemisphere in 2002: Dynamical Aspect of the Ozone Hole Split. SPARC Newsletter, 20, 24-26.

[45] Glatthor, N., von Clarmann, T., Fischer, H., Funke, B., Grabowski, U., Höpfner, M., et al. (2005) Mixing Processes during the Antarctic Vortex Split in September-October 2002 as Inferred from Source Gas and Ozone Distributions from ENVISAT-MIPAS. Journal of the Atmospheric Sciences, 62, 787-800. http://dx.doi.org/10.1175/JAS-3332.1

[46] Ricaud, P., Lefèvre, F., Berthet, G., Murtagh, D., Llewellyn, E.J., Mégie, G., et al. (2005) Polar Vortex Evolution dur- 
ing the 2002 Antarctic Major Warming as Observed by the Odin Satellite. Journal of Geophysical Research, 110, D05302. http://dx.doi.org/10.1029/2004jd005018

[47] Di Biagio, C., Muscari, G., di Sarra, A., de Zafra, R.L., Eriksen, P., Fiocco, G., Fiorucci, I. and Fuà, D. (2010) Evolution of Temperature, $\mathrm{O}_{3}$, CO, and $\mathrm{N}_{2} \mathrm{O}$ Profiles during the Exceptional 2009 Arctic Major Stratospheric Warming as Observed by Lidar and Millimeter-Wave Spectroscopy at Thule $\left(76.5^{\circ} \mathrm{N}, 68.8^{\circ} \mathrm{W}\right)$, Greenland. Journal of Geophysical Research, 115, D24315. http://dx.doi.org/10.1029/2010JD014070

[48] Flury, T., Hocke, K., Haefele, A., Kömpfer, N. and Lehmann, R. (2009) Ozone Depletion, Water Vapor Increase, and PSC Generation at Midlatitudes by the 2008 Major Stratospheric Warming. Journal of Geophysical Research, 114, D18302. http://dx.doi.org/10.1029/2009jd011940

[49] Liu, Y., Liu, C.X., Wang, H.P., Tie, X.X., Gao, S.T., Kinnison, D. and Brasseur, G. (2009) Atmospheric Tracers during the 2003-2004 Stratospheric Warming Event and Impact of Ozone Intrusions in the Troposphere. Atmospheric Chemistry and Physics, 9, 2157-2170. http://dx.doi.org/10.5194/acp-9-2157-2009

[50] Wang, L. and Alexander, M.J. (2009) Gravity Wave Activity during Stratospheric Sudden Warmings in the 2007-2008 Northern Hemisphere Winter. Journal of Geophysical Research, 114, D18108. http://dx.doi.org/10.1029/2009jd011867

[51] Nath, O. and Sridharan, S. (2015) Equatorial Middle Atmospheric Chemical Composition Changes during Sudden Stratospheric Warming Events. Atmospheric Chemistry and Physics Discussions, 15, 23969-23988. http://dx.doi.org/10.5194/acpd-15-23969-2015

[52] Sridharan, S., Sathishkumar, S. and Gurubaran, S. (2012) An Unusual Reduction in the Mesospheric Semi-Diurnal Tidal Amplitude over Tirunelveli $\left(8.7^{\circ} \mathrm{N}, 77.8^{\circ} \mathrm{E}\right)$ Prior to the 2011 Minor Warming and Its Relationship with Stratospheric Ozone. Journal of Atmospheric and Solar-Terrestrial Physics, 89, 27-32. http://dx.doi.org/10.1016/j.jastp.2012.07.012

[53] Baldwin, M.P. and Dunkerton, T.J. (2001) Stratospheric Harbingers of Anomalous Weather Regimes. Science, 294, 581-584. http://dx.doi.org/10.1126/science.1063315 